\title{
On the evolution of orogens: Pressure cycles and deformation mode switches
}

\author{
Marco Beltrando $^{\mathrm{a}, *}$, Jörg Hermann ${ }^{\mathrm{a}}$, Gordon Lister ${ }^{\mathrm{a}}$, Roberto Compagnoni ${ }^{\mathrm{b}}$ \\ ${ }^{a}$ Research School of Earth Sciences, Mills Rd, Australian National University, Canberra 0200, Australia \\ ${ }^{\mathrm{b}}$ Dipartimento di Scienze Mineralogiche e Petrologiche, Via Valperga Caluso 35, I-10125 Turin, Italy
}

Received 23 May 2006; received in revised form 12 January 2007; accepted 16 January 2007

Available online 27 January 2007

Editor: R.W. Carlson

\begin{abstract}
Evidence of two burial-exhumation cycles that took place during a single orogeny has been found in rocks belonging to the Piemonte unit of the Western Alps. An early high pressure event, which resulted from tectonic burial down to pressures of $1.5 \mathrm{GPa}$, was followed by exhumation to ca. $0.20-0.35 \mathrm{GPa}$ as a result of extensional deformation. Renewed shortening culminated in a second burial episode down to pressures of $0.65-0.80 \mathrm{GPa}$, before the final exhumation took place. Existing geochronological data allow only ca. 13-19 Ma for the completion of both burial-exhumation cycles. Therefore, we suggest that the evolution of orogens is characterized by multiple short-lived burial-exhumation cycles related to orogen-scale alternance between shortening and extensional deformation.
\end{abstract}

(C) 2007 Elsevier B.V. All rights reserved.

Keywords: orogenesis; Alps; amphibole; extensional tectonics; pressure-temperature path

\section{Introduction}

Mountain belts represent a prominent feature along convergent plate margins. However, the details of their formation and evolution as a consequence of plate interaction are still largely unclear. Early models envisaged orogenesis as a two-stage process, which involved progressive accretion of terranes to the orogen and their subsequent exhumation to the surface, either in a com-

\footnotetext{
* Corresponding author. Tel.: +612 61253125; fax: +61261258253

E-mail addresses: marco.beltrando@anu.edu.au (M. Beltrando), joerg.hermann@anu.edu.au (J. Hermann),gordon.lister@anu.edu.au (G. Lister), roberto.compagnoni@unito.it (R. Compagnoni).
}

pressional or extensional setting (e.g. [1-4]). Studies of metamorphism have traditionally provided strong support to this two-stage view (e.g. [5]). High pressure metamorphic assemblages, interpreted to result from burial induced by accretion, are usually observed to reequilibrate at lower pressure-temperature conditions, before final exhumation to the surface takes place.

However, recent studies have detected considerable complexities in the evolution of mountain belts. Orogen-scale switches from shortening to extensional deformation and vice versa have been reported from several orogens worldwide [6-10]. It has been proposed that shortening episodes result in tectonic burial and high pressure metamorphism $[7,8]$, whilst extensional episodes culminate in exhumation of rock units and re- 
equilibration of the HP assemblages at lower pressures [9]. Renewed shortening can be inferred by folding of the extensional structures [8] or by their overprint by thrusting [7,10]. As already noted by Azañón and Crespo-Blanc [9], a deformation history characterized by multiple shortening-extension cycles would be expected to leave traces in the metamorphic record. More precisely, if shortening results in crustal (or lithospheric) thickening and extension in crustal (or lithospheric) thinning, then the $P T$ evolution of individual rock units should be characterized by multiple burial-exhumation cycles.

Such $P T$ cycles have so far been inferred only from the thermal history derived from ${ }^{40} \mathrm{Ar} /{ }^{39} \mathrm{Ar}$ spectra of white micas from the Cycladic eclogite-blueschist belt [11]. The preservation of white mica ages that can be related to eclogite facies metamorphism in rocks that later experienced several stages of metamorphic re-equilibration has led Forster and Lister [11] to propose that individual thermal events that culminate in mineral growth are followed by rapid cooling. Therefore the possibility that rapid cooling and/or depressurisation episodes are interposed between various heating-burial events, which are the most likely to be expressed in the metamorphic record, must be taken into account. Petrological evidence of the above mentioned $P T$ evolution would require the presence of metamorphic mineral assemblages indicative of lower pressure (and/or temperature) conditions interposed between two mineral assemblages recording higher pressure (and/or temperature).

To test for the presence of cyclic $P T$ histories within a mountain belt, we investigated in detail the metamorphic and deformation history of the Piemonte units of the Western Alps, in Italy. Two burial-exhumation cycles that took place during the Alpine orogenesis have been found. Combined structural data indicate that the first exhumation episode was coeval with orogen-scale extension. A deformation mode switch from extension to shortening was responsible for reburial, before the studied rocks reached near-surface conditions.

This new information, combined with existing geochronological data, provides new fundamental constraints on the evolution of the Western Alps and, by inference, on orogenic belts in general. The emerging picture indicates that the evolution of orogens is characterized by multiple short-lived burial-exhumation cycles coupled with switches from shortening to extensional deformation.

\section{Geological setting}

The Alps formed as a result of the convergence between Adria, a promontory of Africa, and the European plate. The northward movement of Adria since the Cretaceous (e.g. [12]) resulted in progressive accretion to the evolving Alpine orogen of oceanic and continental (Austroalpine, Briançonnais) plates and micro-plates interposed between Adria and Europe s.s. A branch of the Tethys known as the Piemonte-Ligurian ocean became part of the Alpine orogen in the Eocene (e.g. [13]). The Piemonte units of the Western Alps are interpreted as remnants of this oceanic basin and of the sedimentary sequences deposited along its margins (e.g. $[14,15]$ ). Heterogeneous peak- $P$ conditions have been estimated from different parts of the Piemonte domain (e.g. [16]). A contact between Piemonte units that underwent eclogite and blueschist facies metamorphism, respectively, can be followed for the entire length of the Western Alps (Fig. 1, [17]). This contact is underlined for most of its length by slices of exotic rock units mainly of Austroalpine continental affinity (e.g. [18]). The early hypothesis of Ballèvre and Merle [16] as to the extensional nature of this contact in the north-western Alps has later been confirmed by detailed structural and geochronological studies [19-21]. In particular, Reddy et al. [20] showed that the retrogression and exhumation of the eclogitic Piemonte unit was contemporaneous to the top-to-the-east shearing along the contact with the overlying blueschist Piemonte unit. Since the footwall was being exhumed relative to the hangingwall as a result of shearing along their contact, such interface must have been responsible for crustal excision through extensional deformation [22].

\section{Field observations}

The regional geometry of the contact between the eclogite and blueschist facies Piemonte units has been the subject of recent investigation, particularly in the area located between the Gran Paradiso massif and the Aosta Valley (Fig. 1). As already shown further to the north $[16,18,21]$ the contact is characterized by the presence of small rock slices of variable size that have no lithological equivalent either in the immediate footwall or in the hangingwall. These exotic units comprise the continental basement rocks of the Tour Ponton [23] and Eaux Rousses [24] units and the Mesozoic continental shelf deposits of the Faisceau de Cogne [25]. The former displays a close affinity with the Austroalpine units, which are located in a more internal position in the Western Alpine orogen (Fig. 1a), whilst the latter resembles the sedimentary cover typical of the more external continental Briançonnais domain (Fig. 1a, [25]).

Shear fabrics related to the extensional episode are ubiquitously found along the contact between the eclogitic and blueschist units and in the well exposed 


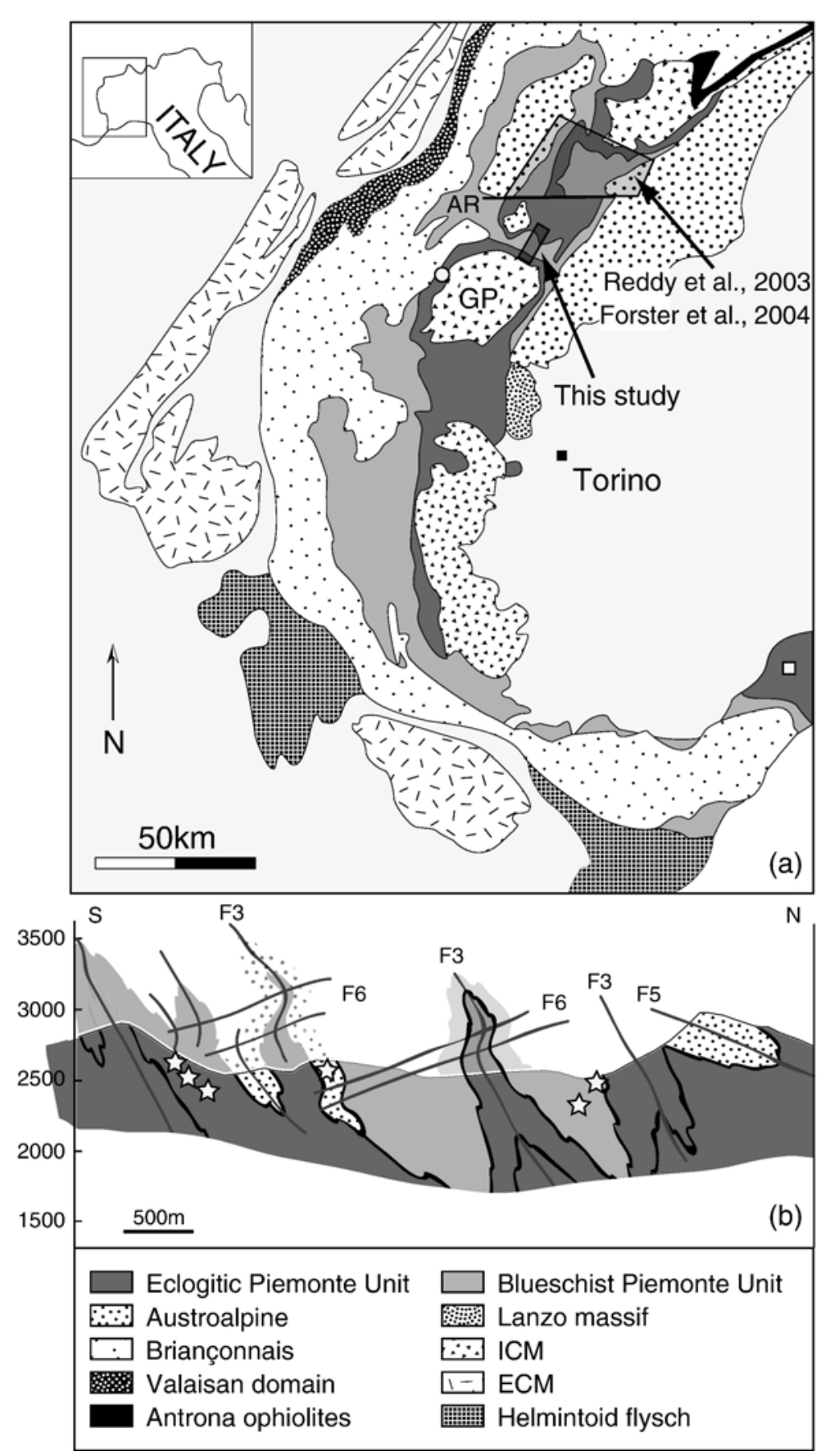

Fig. 1. (a) Simplified tectonic map of the Western Alps (modified from Schwartz et al. [17]). Shaded area indicates the position of the study area, between the Gran Paradiso Massif (GP) and the Aosta-Ranzola Fault (AR). A N-S profile (b) shows folding of the contact between the eclogitic and blueschist facies Piemonte units. Stars indicate location of studied samples, which are, from left to right, ALP0482, ALP0423, ALP0481, MB0519, ALP0417 and MB0530. Locations for which an analogous metamorphic evolution can be postulated on the basis of petrographic observations conducted by the authors (circle) or extrapolated from the literature (square) are also shown. Also indicated is the area studied by Reddy et al. [20] and Forster et al. [21]. ICM=Internal Crystalline Massifs; ECM=External Crystalline Massifs.

contacts between Austroalpine and Piemonte units (Fig. $2 \mathrm{a}$ and $\mathrm{b}$ ). C-type shear bands [26] and mica fish (Fig. 2b) are common [27]. WNW-ESE trending stretching lineations marked by elongated quartz or calcite rods in the calcschists and by elongated amphiboles in the mafic rocks are found on the $\mathrm{C}$ planes. Rootless folds marked by 

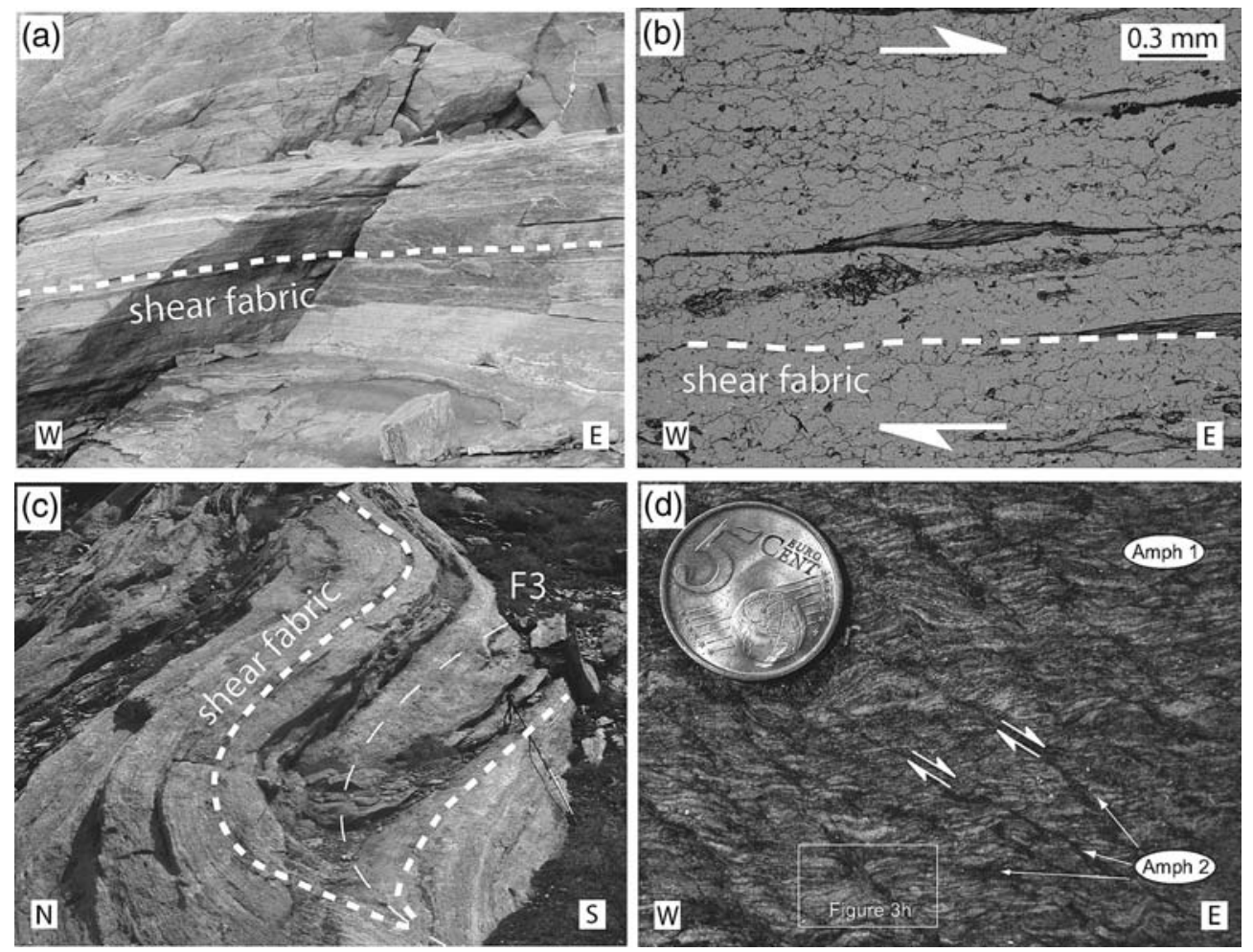

Fig. 2. (a) Shear zone in the Tour Ponton continental basement unit at the contact with the eclogitic Piemonte unit. Photomicrograph with mica fish (b) shows the mylonitic nature of this contact. Shear-related fabrics are then affected by later upright and recumbent folding (c). Upright folding is followed by the formation of rare east-dipping shear planes accommodating top-to-the east deformation (d). Amphibole 2 is observed to grow in the shear planes (see text for explanation).

quartzitic layers are commonly observed in the calcschists of the eclogitic unit cropping out in the immediate footwall of the contact. Parallelism between fold axes and stretching lineation suggests that those folds formed during the shearing event, although they may also represent pre-shear folds that have been stretched out and re-oriented during shearing (e.g. [28]).

Large-scale folding of the contact between the eclogitic and blueschist Piemonte units after its formation resulted in the repetition of the eclogitic unit and Austroalpine slices on both sides of the Urtier Valley (Fig. 1b). Upright $\left(\mathrm{F}_{3}\right)$ and recumbent $\left(\mathrm{F}_{5}\right)$ folds (Figs. 1b and 2c), which have also been found in neighbouring areas [29], are the most pervasive postshear deformation episode. Shear fabrics related to the formation of the tectonic contact are also folded at all scales (Fig. 2b). Sense of shear as deduced from the $\mathrm{C}-\mathrm{S}$ asymmetry varies as a consequence of $\mathrm{F}_{3}$ folding, being top-E on the normal limbs of $F_{3}$ folds and top-W on the reverse limbs. Upright $F_{3}$ folding was followed by the formation of rare east-dipping shear bands (Fig. 2d) that accommodated top-to-the-east deformation $\left(\mathrm{D}_{4}\right)$. Later, less pervasive recumbent folding $\left(\mathrm{F}_{5}\right.$ and $\left.\mathrm{F}_{6}\right)$ affects all older structures (Fig. 1b).

\section{Sample description}

\subsection{Petrography}

Mafic rocks have been chosen to determine the $P T$ evolution of the study area with the intention to tie it to the deformation history outlined above. Mafic rocks are good candidates to determine $P T$ histories in the greenschist to lower amphibolite facies conditions, due to the abundant presence of amphibole, whose composition is very sensitive to relative variations in $P T$ conditions (see below).

A Fe-Ti metagabbro (ALP0481; GPS coordinates in the WGS72: 0379514; 5048636) from a low strain zone contains the most complete record of the metamorphic evolution (Table 1). Abundant rutile, relict garnet and rare omphacite represent the only traces of an early eclogite facies metamorphic event. Garnets are generally found as small crystals with irregular shapes 
Table 1

Minerals found in the Fe-Ti metagabbro ALP0481

\begin{tabular}{|c|c|c|c|c|c|c|}
\hline stage & Burial & Exhun & & & Burial & Exhumation \\
\hline \multirow{4}{*}{$\begin{array}{l}\text { garnet } \\
\text { rutile } \\
\text { pyroxene } \\
\text { amphibole } \\
\text { epidote } \\
\text { plagioclase } \\
\text { chlorite } \\
\text { titanite } \\
\text { quartz }\end{array}$} & & jd19 & $\mathrm{jd} 3$ & \multirow[b]{2}{*}{ amph1 } & \multirow[b]{2}{*}{ amph2 } & \multirow[b]{2}{*}{ amph3 } \\
\hline & & & & & & \\
\hline & & & & & & \\
\hline & & & & & & \\
\hline Deformation & & extensional shearing & & & upright folding/ & \\
\hline Age (Ma) & $50-44$ & $42-38$ & & & top-E shear & $>31$ \\
\hline
\end{tabular}

Also indicated is the jadeite content in the oldest and youngest pyroxenes. The relationship between deformation and mineral growth and the ages of the different episodes are also shown (see text for explanation and references).

included in amphibole porphyroblasts. Rutile crystals several millimeters in size are usually found in distinct rutile-rich domains. Two rims are ubiquitously observed around rutile. The inner rim is composed of pyrite, whilst the outer contains exclusively titanite. Rare pyroxenes of omphacitic composition are present both as inclusions in amphibole porphyroblasts (Fig. 3a) and in the rock matrix (Fig. 3b). Small (50-100 $\mu \mathrm{m})$, non-idioblastic pyroxenes displaying the same crystallographic orientation over sub-mm areas are found included in plagioclase in the matrix. Compositional zoning can be observed under crossed-polarizers in rare, larger pyroxene crystals included in amphibole (Fig. 3a). The crystal shown in Fig. $3 \mathrm{a}$ is also observed to break down to a fine grained symplectite composed of plagioclase and pyroxene.

Pyroxene + plagioclase aggregates in the rock matrix are statically overprinted and largely obliterated by poikiloblastic $\mathrm{mm}$-size green amphibole associated with albite (Fig. 3b, Table 1). These amphiboles (amphibole 1) are characterized by irregular margins and by the presence of embayments of albite.
Large porphyroblasts of green-blue amphibole (amphibole 2) overprint all older mineral assemblages (Fig. 3b, Table 1). These amphiboles range in size from ca. $200 \mu \mathrm{m}$ to ca. $5 \mathrm{~mm}$. They are heterogeneously distributed in the rock and they lack any kind of crystallographic or shape preferred orientation. Amphibole 2 is characterized by idioblastic shape and straight contacts with chlorite, albite and epidote porphyroblasts are commonly observed (Fig. 3c). Compositional zoning, with amphibole 2 crystals evolving towards dark green amphibole (amphibole 3) towards the rims, is observed (Fig. 3d, Table 1). Amphibole 3 is particularly common at the contact between amphibole 2 and garnet. Plagioclase is normally found as very large poikiloblasts including garnet, rutile and omphacite. Fe-chlorite is abundant in the rock matrix and is sometimes observed in ghost structures over the rims of garnet crystals. Fine grained quartz crystals are also found in the matrix.

A similar, but less complete, metamorphic record can be observed in more deformed metamafic rocks from the same area that also allow to unravel the connections

Fig. 3. (a) X-ray map of a pyroxene crystal showing variations in $\mathrm{Al}$ abundance. A compositional zonation perpendicular to the length of the pyroxene can be observed. The upper part of the crystal is observed to break down into a symplectite made of pyroxene with a lower jadeite component (darker) and albite (bright). The pyroxene is enclosed in a large amphibole 2 crystal. The dashed line indicates the position of the compositional profile shown in Fig. 4a. (b) BSE image of albite (dark) + pyroxene symplectites can also be found in the matrix, where they are overgrown by poikiloblastic amphibole 1. Amphibole 2 crystals are observed to overgrow both the pyroxene + albite symplectites and the earlier amphibole generation (amphibole 1). Numbers in circles indicate amphibole generation. (c) Transmitted light image of amphibole 2 is in equilibrium with epidote, albite and chlorite, as indicated by the sharp, straight grain boundaries. (d) Amphibole porphyroblasts are characterized by blue-green cores (amphibole 2) evolving towards dark-green amphibole at the rim (amphibole 3). (e) Most metamafic rocks in the study area are characterized by the presence of a differentiated fabric, considered equivalent to the shear fabric observed in neighbouring rocks (Fig. 2a), completely overprinted by static amphibole $1+$ albite + epidote + chlorite. This overprint was followed by the upright folding event (f), during which albite porphyroclasts recrystallised (g) and amphibole 2 formed Notice the subgrains in the hinge zone of $\mathrm{F}_{3}$. (h) In another sample from a metamafic rock (ALP0423) amphibole 2 is found along shear planes that overprint an amphibole $1+$ albite assemblage. 

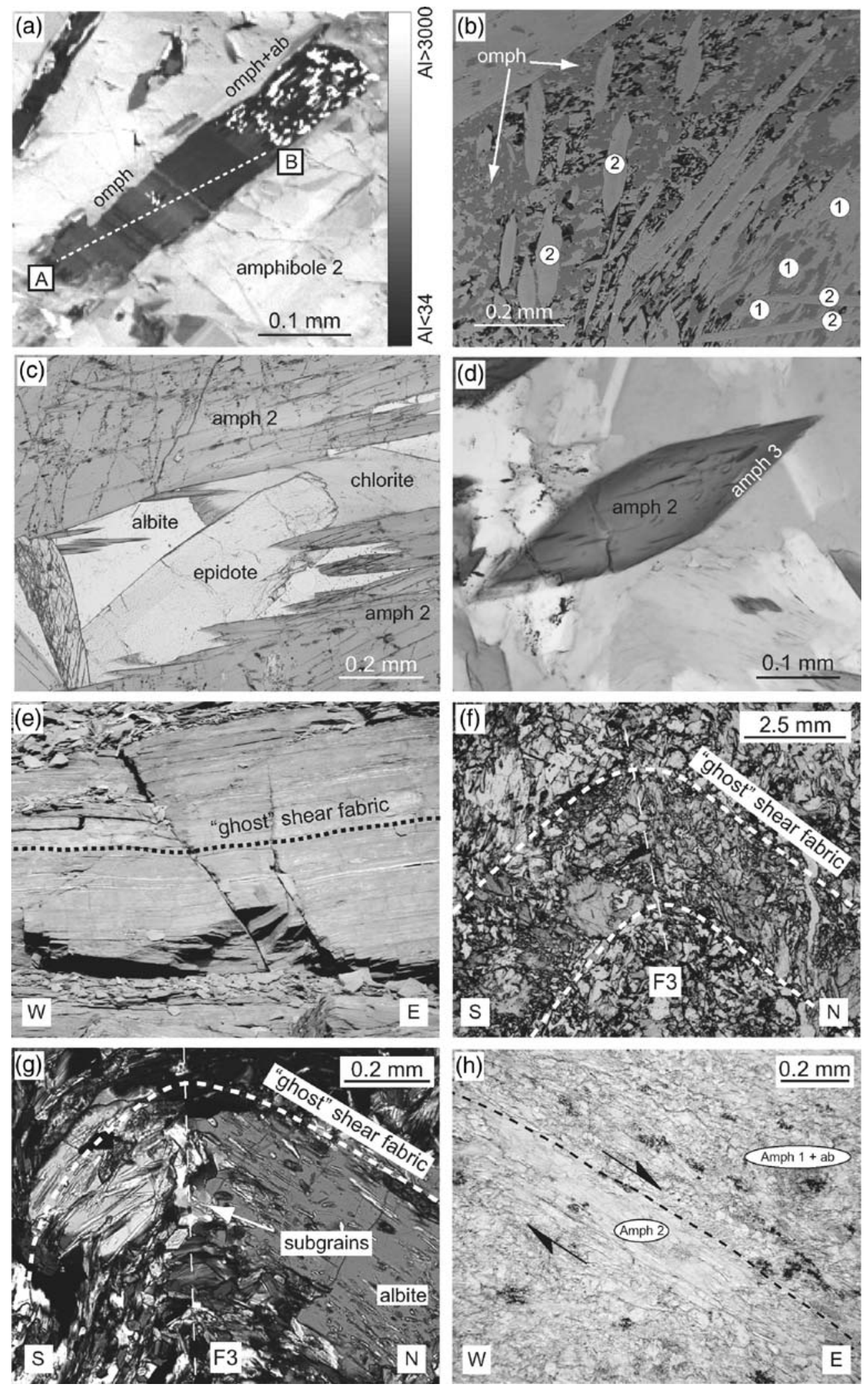
between metamorphic events and deformation history. Most metamafics are generally characterized by a pervasive compositional layering at the $\mathrm{mm}$ to sub-mm scale (Fig. 3e). This compositional layering, which is oriented parallel to the contacts with the other lithologies, is defined by alternating amphibole $1+$ albite + chlorite and epidote + albite-rich layers. The minerals do not display any preferred orientation, a feature that indicates they grew statically over a pre-existing differentiated fabric. Correlation with the neighbouring calcschists and continental basement units (cfr. Figs. 2a and $3 \mathrm{e}$ ) indicates that such fabric was related to the extensional shearing event that resulted in the juxtaposition of the eclogitic and blueschist Piemonte units. The static overprint of the shear fabric preceded $\mathrm{F}_{3}$ folding (Fig. 3f), as indicated by the presence of subgrains at the margins of albite porphyroclasts in the hinge zone of $\mathrm{F}_{3}$ folds (Fig. 3g). Amphibole 2 is commonly observed in the hinge of $\mathrm{F}_{3}$ folds, suggesting that it formed during the episode of upright folding (Table 1).

Overprinting between amphibole 1 and amphibole 2 is observed in all metamafic rocks. In ALP0423 (GPS coordinates: $0379159 ; 5048337$ ), in particular, amphibole 1 is observed to grow statically over a pre-existing fabric together with albite. This newly formed metamorphic assemblage is then substituted by amphibole 2 and epidote along later east-dipping shear planes that accommodate top-to-the-east movement during $\mathrm{D}_{4}$ (Fig. $3 \mathrm{~h}$ ).

\subsection{Mineral compositions}

The composition of all the mineral phases observed in ALP0481 has been determined with the electron microprobe CAMECA SX100 at the Research School of Earth Sciences, Australian National University, Canberra. An operating voltage of $15 \mathrm{kV}$ and a beam current of $20 \mathrm{nA}$ have been chosen for the analysis. Mineral compositions have been calculated following the normalization procedure outlined in Table 2. Compositions of all mineral phases can be found in Table 2 .

$\mathrm{X}$-ray mapping of a pyroxene crystal included in an amphibole 2 porphyroblast confirms the presence of a marked compositional zoning with abrupt changes parallel to its length (Fig. 3a). A profile across the different growth zones (Fig. 4a) reveals that the jadeite component in the omphacite varies from a maximum of $19 \%$ to a minimum of $7 \%$. The omphacite porphyroclast is observed to break down along its upper tip to a fine grained symplectite of pyroxene (jadeite 3\%) and albite (Fig. 3a).

Three amphibole generations can be distinguished in ALP0481 on the basis of overprinting relationships and optical properties (Table 1, Fig. 3b,c,d). These three amphibole generations are characterized by markedly different compositions (Fig. $4 \mathrm{~b}$ and Table 2). $\mathrm{Na}$ in the M4 site, which is a measure of the glaucophane substitution and is related to pressure variations (see below), is observed to increase from amphibole 1 to amphibole 2 and then to decrease slightly again (Fig. 4a). The molar fraction of $\mathrm{Na}$ in the A site, which is related to the edenite substitution, shows a slight increase from amphibole 1 to amphibole 2 and then a more marked increase going towards amphibole 3 (Table 2).

Using the nomenclature outlined in Leake [30], the composition of amphibole 1 spreads from actinolite to hornblende, whilst amphibole 2 ranges from barroisite to hornblende and amphibole 3 is pargasite.

The different amphibole generations observed in ALP0481 (Fig. 4b) are also found in the other metamafic rocks from the study area (Fig. 4c). The widespread occurrence of amphibole 1 and amphibole 2 has allowed to constrain their timing of formation with respect to the deformation history. The composition of the amphiboles that formed statically over the preexisting shear fabric overlaps with amphibole 1 from ALP0481 (Fig. 4c). The amphiboles that replace amphibole 1 in the hinge zones of upright $F_{3}$ folds and in the east-dipping shear planes, instead, display the same composition as amphibole 2 from ALP0481 (Fig. 4c).

Chlorine content in the different amphibole generations was measured to test whether the studied rock behaved as a closed system during its metamorphic evolution. This is important to ascertain that the variations in amphibole composition are related to mineral reaction triggered by variations in $P T$ conditions, rather than by changes in bulk rock chemistry induced by the influx of external fluids. Differences in $\mathrm{Cl}$ content between different generations of amphiboles would have pointed towards a sudden input of externally derived fluids [31]. The results showed that chlorine is present in very low quantities and no significant differences have been found between the three generations of amphibole (Table 2).

\subsection{PT estimates}

The mineral compositions as determined in the previous section (Table 2) have been used to estimate the pressure-temperature evolution of the metamafics with published geothermobarometers.

The albite $=$ jadeite + quartz reaction (e.g. [32]) is widely used to determine the pressure conditions of metamorphism. With increasing pressure albite breaks down into the assemblage jadeite+ quartz, with a volume reduction of $17.8 \mathrm{~cm}^{3} / \mathrm{mol}$ [33]. If omphacite is present, this 


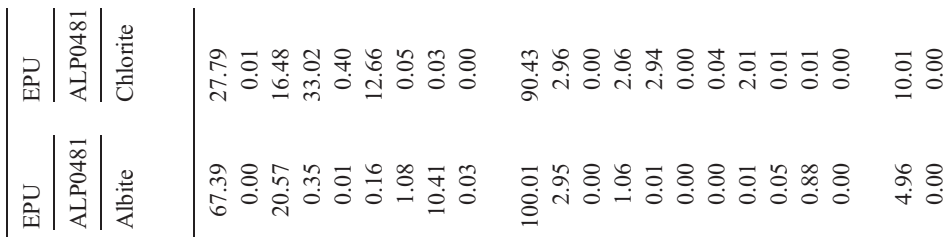

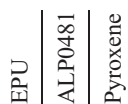

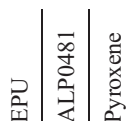

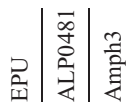

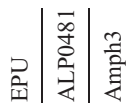

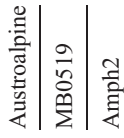

总竞|

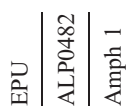

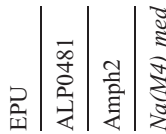

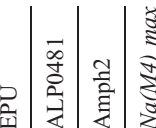

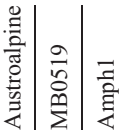

总|

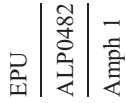

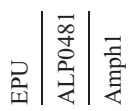

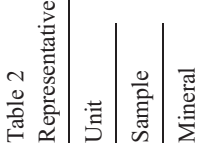

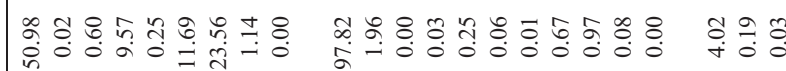

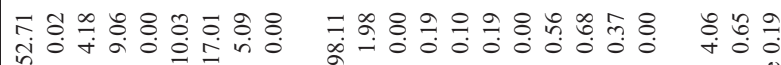

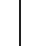

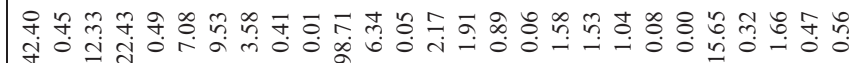

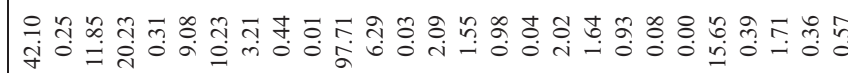

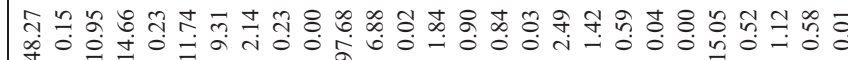

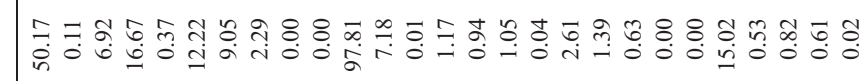

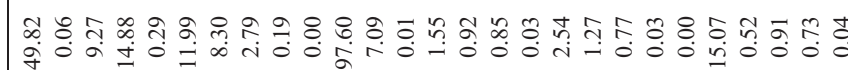

s.

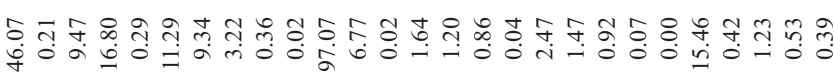

(2)

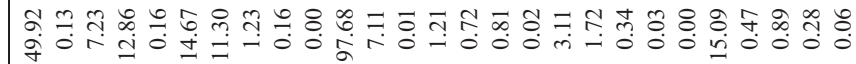

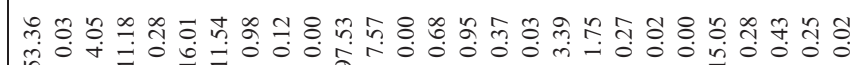

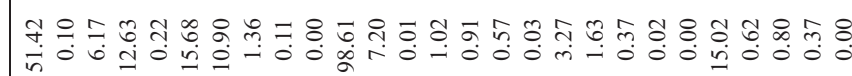

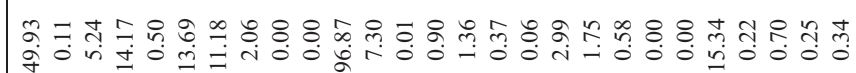

(1)

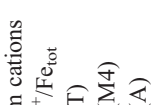

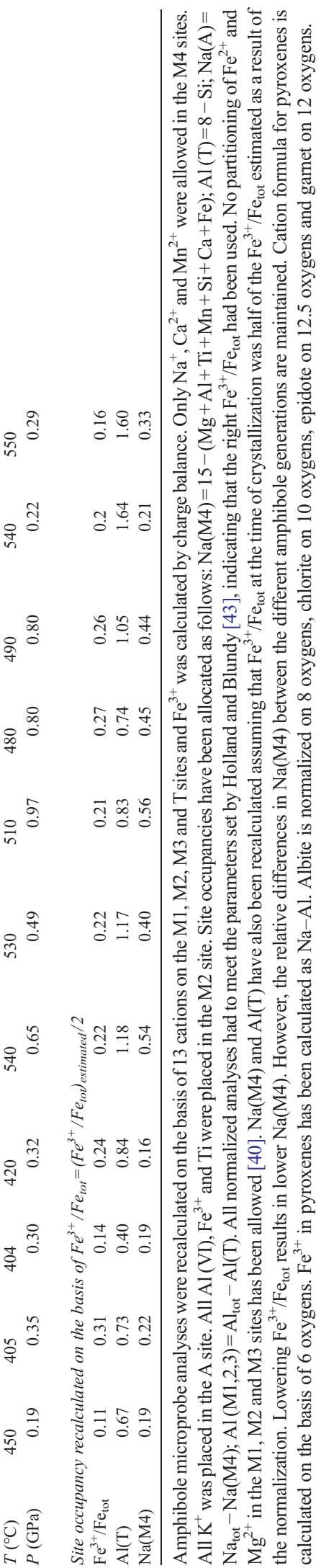


univariant reaction translates into a continuous reaction spanning a wide range of pressures and for which the isopleths have been determined experimentally [34]. Measurements of the jadeitic component in the omphacitic pyroxene provide a direct estimate of the pressure of reequilibration of the studied mineral when found in equilibrium with quartz and albite.

The observed variation in jadeite content in the pyroxene from ALP0481 (Fig. 3a and Table 2) can be related to different stages of the $P T$ history experienced by the rock. The zoning observed in the larger crystal (Fig. 4a), with jadeite ranging from $19 \%$ to $7 \%$ indicates that the different growth stages recorded a decompression history from $0.7-0.9 \mathrm{GPa}$ to $0.4-0.5 \mathrm{GPa}$ (Fig. 5). The highest values of pressure indicate that the pyroxenes highest in jadeite formed subsequently to the rutile+ garnet assemblage, which is indicative of eclogitic conditions. Pressures of $1.5 \mathrm{GPa}$ and temperatures of 500 $550{ }^{\circ} \mathrm{C}$ have been estimated for this event on less retrogressed samples from the same area [35].

The jadeitic component in the omphacites found in the symplectite with albite ranges between $3 \%$ and $8 \%$, indicating that the symplectite formed at pressures down to $0.15-0.2 \mathrm{GPa}$ (Fig. 5). These values should only be considered as first-order estimates, since the position of the isopleths for low jadeite contents is not determined with great precision. The geobarometer based on the jadeite content in pyroxene does not provide any constraint on the $T$ of crystallization. However, published $P T$ paths for rock units form the Western Alps are invariably characterized by moderate cooling during decompression after the eclogitic event (e.g. [36]). Therefore, the $P T$ trajectory obtained from the analysis of the omphacite composition indicates that the studied rock, after the eclogitic event, was exhumed to shallow crustal levels (Fig. 5). These results are confirmed by the crystallization of amphibole 1 of actinolitic/hornblende composition, in a hydration reaction typically observed in the retrogression of pyroxenes under greenschist facies conditions.

The response of amphibole composition to changes in pressure and temperature has long been recognized (e.g. [37-39]). The basic crystallographic formula of amphiboles can be simplified as $\mathrm{A}_{0-1}(\mathrm{M} 4)_{2}(\mathrm{M} 1-3)_{5} \mathrm{~T}_{8}$ where $\mathrm{T}$ indicates the tetrahedral and $\mathrm{A}, \mathrm{M} 1-3,4$ represent the additional cation sites. Coupled substitutions in the basic tremolitic composition $\mathrm{Ca}_{2} \mathrm{Mg}_{5} \mathrm{Si}_{8} \mathrm{O}_{22}(\mathrm{OH})_{2}$ can be related to the conditions of crystallization [39]. In particular, the glaucophane $[2 \mathrm{Ca}(\mathrm{M} 4)+2 \mathrm{Mg}(\mathrm{M} 1-3)=$ $2 \mathrm{Na}(\mathrm{M} 4)+2 \mathrm{Al}(\mathrm{M} 1-3)]$ and the edenite $[\mathrm{Si}(\mathrm{T})=\mathrm{Na}(\mathrm{A})+$ $\mathrm{Al}(\mathrm{T})$ ] substitutions are considered good indicators of pressure and temperature variations, respectively. Crystallographic studies [40] have shown that replacement of $\mathrm{Mg}^{2+}$ or $\mathrm{Fe}^{2+}$ by $\mathrm{Al}^{3+}$ in the octahedral M2 site causes a considerable contraction in the octahedral strip, lowering the unit cell volume of amphiboles. The resulting crystal is therefore more stable at higher pressures. The excess charge resulting from this substitution is balanced by $\mathrm{Na}^{+}$replacing $\mathrm{Ca}^{2+}$ in the M4 site. Therefore, the amount of $\mathrm{Na}^{+}$content in the M4 site, which is a measure of the glaucophane substitution [39], can be used to infer the pressure of crystallization [37,38]. Early semi-quantitative methods $[37,38]$ have recently been implemented by the geothermobarometer of Okamoto and Toriumi [41], which allows to determine the $P T$ conditions of stability of amphiboles in the ep $+\mathrm{chl}+\mathrm{ab}+\mathrm{qtz}$ assemblage. This method is particularly useful for mafic metamorphic rocks, for which the stability of the amph $+\mathrm{chl}+\mathrm{ep}+\mathrm{plag}+\mathrm{qtz}$ assemblage spans a wide range of $P T$ conditions [42].

The geothermobarometer of Okamoto and Toriumi [41] has been used to estimate the condition of crystallization of the three amphibole generations observed in the metamafics. Estimates have been carried out on representative compositions from different samples (Fig. 4 and Table 2). This resulted in $P=0.20-0.35 \mathrm{GPa}$ and $T=$ $400-450{ }^{\circ} \mathrm{C}$ for amphibole 1 (Table 2). These results are in line with the qualitative geobarometer of Brown [37], which estimates pressures between 0.2 and $0.3 \mathrm{GPa}$ for amphiboles containing $0.1-0.3 \mathrm{Na}(\mathrm{M} 4)$ p.f.u. $P T$ conditions of crystallization of amphibole 2 have been calculated for several representative compositions (Table 2). Estimates of the pressure of crystallization are generally in the $0.65-0.8 \mathrm{GPa}$ range, with rare exceptions (Table 2). Several structurally controlled amphibole 2 crystals yielded $P \approx 0.80 \mathrm{GPa}$ and $T=480-490^{\circ} \mathrm{C}$ (Table 2). $P T$ conditions of crystallization of amphibole 3 have been calculated for a composition relatively high in $\mathrm{Na}(\mathrm{M} 4)$, representative of

Fig. 4. (a) Compositional profile across the pyroxene crystal shown in Fig. 2a. The jadeite component is observed to vary from 7\% to $19 \%$, indicating that the different growth zones observed in Fig. 3a recorded different parts of the exhumation path. (b) diagram illustrating the Na content in the M4 sites for the different generations of amphibole crystals found in ALP0481 (b) and in all the metamafics that have been the subject of this study (c). Each generation defines a clear cluster characterized by distinctive $\mathrm{Na}$ content. $\mathrm{Na}$ in the M4 site is observed to increase from amphibole 1 to amphibole 2. These variations indicate that the different amphibole generations crystallized at different depths. Larger square in (b) indicates the amphibole 2 composition that has been used to estimate the $P T$ conditions of crystallization for ALP0481. Halving the $\mathrm{Fe}^{3+} / \mathrm{Fe}_{\text {tot }}$ results in shifting of data points towards lower $\mathrm{Na}(\mathrm{M} 4)$ and $\mathrm{Al}(\mathrm{T})$ values (triangle, circle and square with white filling). However, the relative position of the different clusters does not change. 
the majority of measured crystals and for a composition characterized by lower $\mathrm{Na}(\mathrm{M} 4)$. The former yielded $T=$ $550{ }^{\circ} \mathrm{C}$ at $P=0.29 \mathrm{GPa}$, whist the latter yielded $T=540{ }^{\circ} \mathrm{C}$ at $P=0.22 \mathrm{GPa}$ (Table 2 and Fig. 5). The majority of amphibole 3 crystals formed at $T=540-550{ }^{\circ} \mathrm{C}$ and $P=0.22-$ $0.29 \mathrm{GPa}$. The common (but not exclusive) presence of

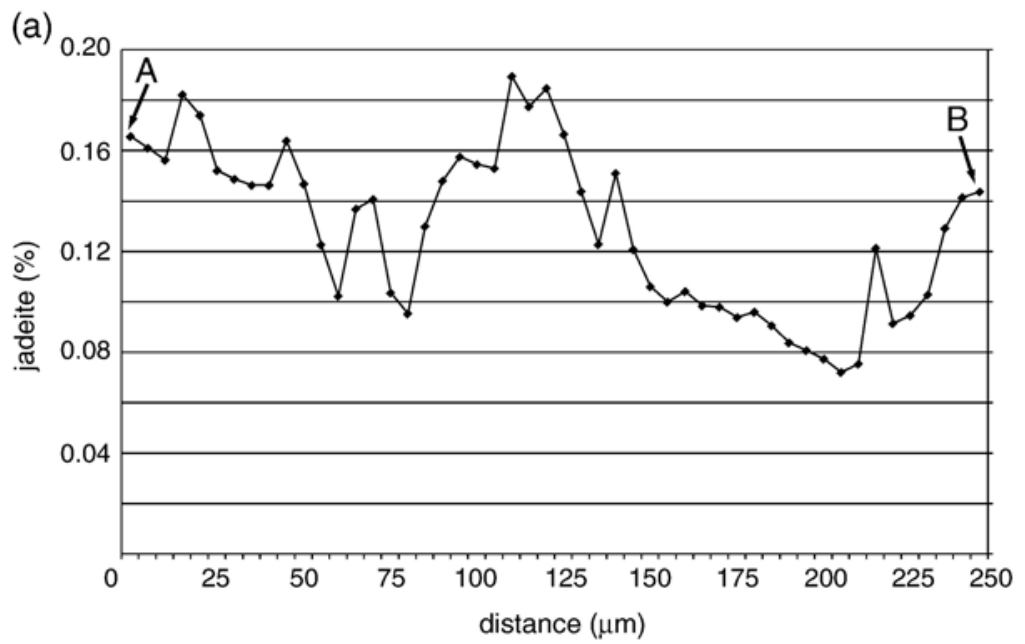

(b) Amphibole composition-sample ALP0481

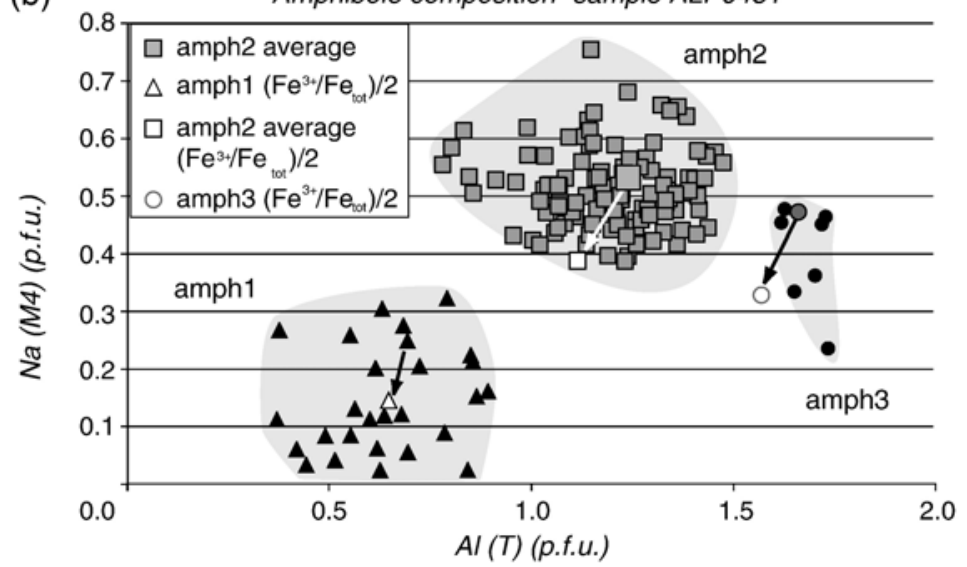

(c) Amphibole composition and microstructures

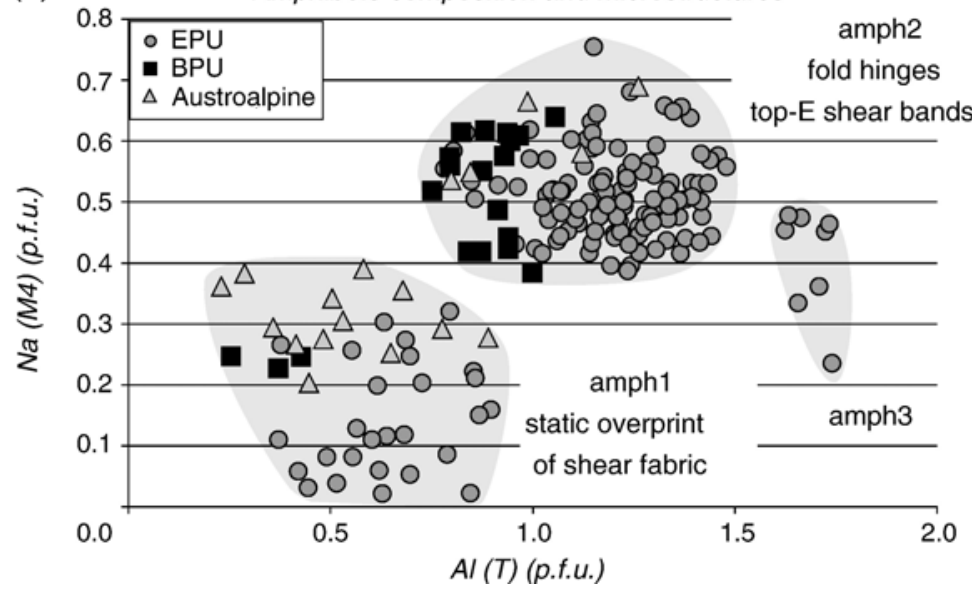




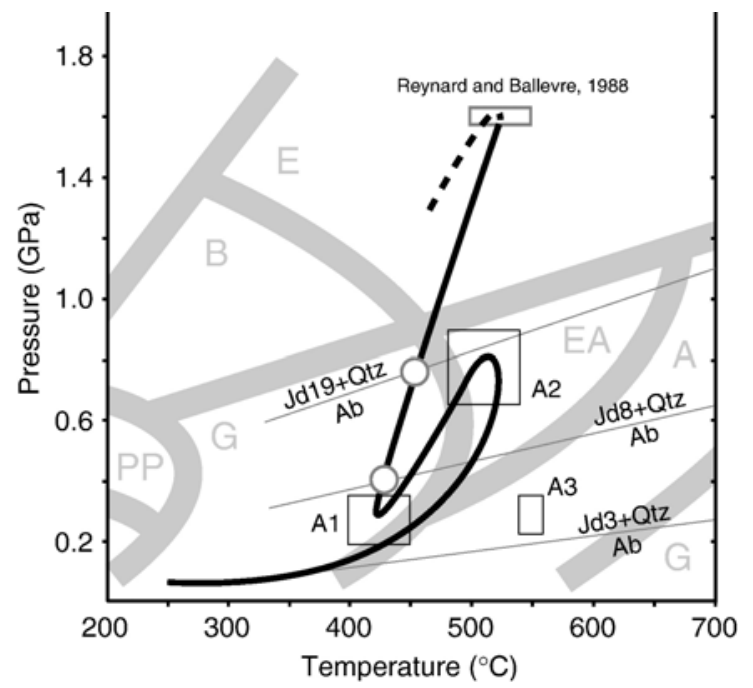

Fig. 5. Pressure-temperature path for the studied rock. The variations in jadeite (jd) content in pyroxene allow to constrain the first exhumation episode. Rectangles indicate the $P T$ conditions estimated for the stability of the three amphibole generations (A1, A2 and A3). Amphibole 3 has not been used to constrain the $P T$ path (see text for explanation). Note that lines connecting the individually determined points in the $P T$ space do not necessarily represent true exhumation paths followed by the studied rock (see Forster and Lister [11]). The fields of the different metamorphic facies are also indicated in grey (from Spear [49]). $\mathrm{E}=$ eclogite facies; $\mathrm{B}=$ blueschist facies; $\mathrm{PP}=$ prehnite-pumpellyite facies; $\mathrm{G}=$ greenschist facies; $\mathrm{EA}=$ epidote-amphibolite facies; $\mathrm{A}=$ amphibolite facies; $\mathrm{G}=$ granulite facies.

amphibole 3 at the contacts between amphibole 2 porphyroblasts and garnet may indicate that the latest amphibole generation formed in a quartz-undersaturated local environment. Therefore, the adoption of the Okamoto and Toriumi [41] geothermobarometer may lead to incorrect estimates of the PT estimates for the formation of amphibole 3. This suggestion is further supported by the absence of plagioclase of oligoclase composition, which would be expected at the temperatures estimated for the formation of amphibole 3, which are well within the amphibolite facies field. Therefore, exhumation after the second pressure peak was probably associated with cooling near or along the transition between the epidote-amphibolite and amphibolite facies.

Projection of the above estimates in a $P T$ diagram (Fig. 5) shows that, after the crystallization of amphibole 1 , the studied rocks underwent a renewed increase in pressure before their final exhumation to the surface took place. The path that followed after the second pressure peak is less well constrained, but was probably characterized by contemporaneous decompression and cooling. The similarities displayed by the amphibole compositions in metamafics sampled from the eclogitic
Piemonte unit, the blueschist Piemonte unit and the Austroalpine slices (Fig. 4c) also indicate that they shared a common pressure-temperature history starting at least from the crystallization of amphibole 1 .

The quantitative estimates on the pressure and temperature of crystallization of the studied samples are dependant on the Na content in the M4 site (glaucophane substitution) and in the A site (edenite substitution). The occupancy of the M4 site by Na is in turn strongly linked to the oxidation state of $\mathrm{Fe}$. In the normalization procedure adopted here [43], all $\mathrm{Fe}^{3+}$ is accommodated in the M2 site, resulting in a charge excess equivalent to the addition of $\mathrm{Al}$ (M1-3), which is typical of the glaucophane substitution. As a consequence, $\mathrm{Na}$ is required in place of $\mathrm{Ca}$ in the M4 site for charge balance. $\mathrm{Fe}^{3+} / \mathrm{Fe}^{2+}$ calculated for each individual analysis (Table 2) represents the upper limit for amphibole where local charge balance is satisfied. Lower $\mathrm{Fe}^{3+} / \mathrm{Fe}^{2+}$ results in a cummingtonite component ( $\mathrm{Mg}, \mathrm{Fe}$ in $\mathrm{M} 4)$ and hence in less $\mathrm{Na}$ being attributed to the M4 site, with the consequent decrease in glaucophane component in amphibole. However, a sensitivity test (Table 2) shows that even if the $\mathrm{Fe}^{3+}$ / $\mathrm{Fe}^{2+}$ values at the time of crystallization had been half of the estimated ones, the relative difference in $\mathrm{Na}$ (M4) between the different amphibole generations would have remained basically unaltered (Fig. 4 and Table 2). Therefore, whilst there is a possibility that the absolute values for the $P T$ conditions of crystallization of the actinolitic and barroisitic amphiboles may be slightly lower than those provided above, their relative position in the $P T$ space, with barroisite lying at higher pressures than actinolite, remains unaltered. This result is also in accordance with observations from other authors (e.g. $[37,38,40,44])$.

Therefore, the $P T$ evolution recorded in the metamafics of the study area is characterized by two distinct pressure cycles (Fig. 5). The validity of these results is based on clear overprinting relationships (Fig. 3a,b and d) and the existence of the first pressure low is a result of two independent geobarometers based on pyroxene and amphibole composition.

\section{Discussion}

\subsection{The link between metamorphism and structure}

The results presented in the previous section indicate that rocks belonging to the eclogitic Piemonte unit, blueschist Piemonte unit and Austroalpine slices underwent two burial-exhumation cycles. For the eclogitic Piemonte unit, the first tectonic burial culminated in metamorphism under eclogite facies conditions (Figs. 5 and 6a). 

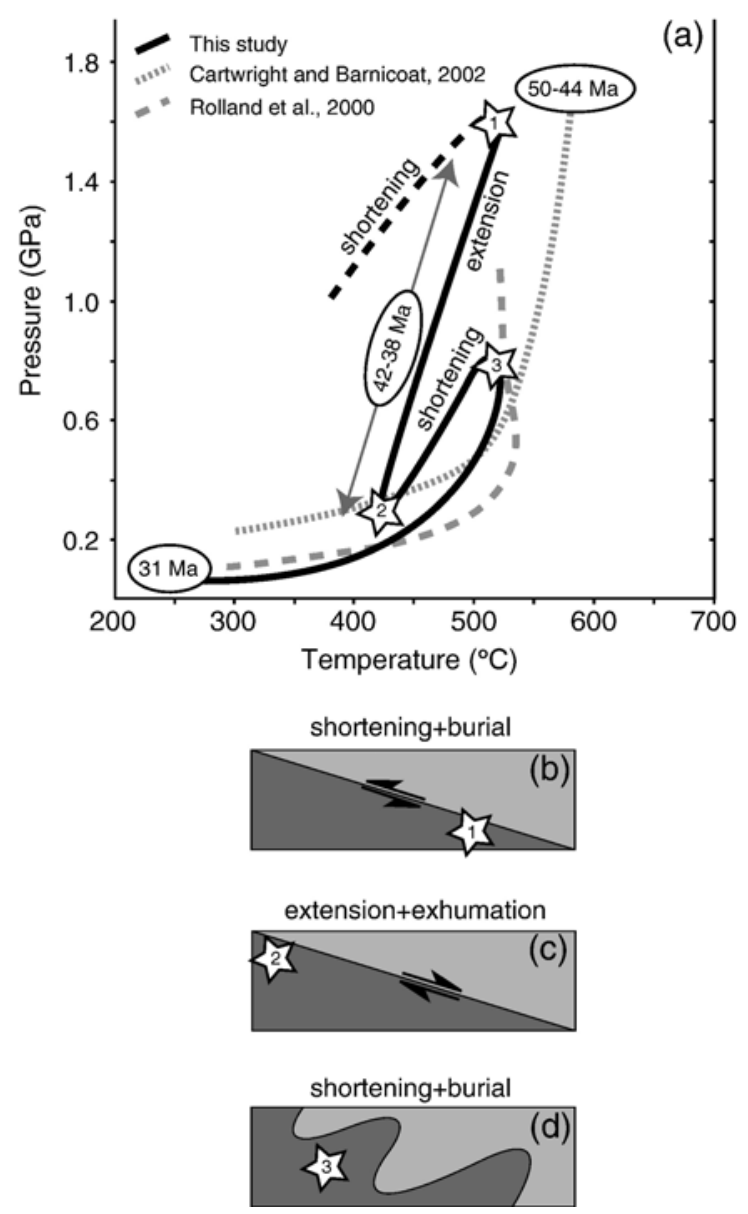

Fig. 6. Comparison between the $P T$ evolution experience by the studied rock and $P T$ paths provided for other parts of the eclogite facies Piemonte unit. Notice that all $P T$ paths intersect or almost intersect in proximity of the conditions estimated for the crystallization of amphibole 2. This may indicate that the samples studied by Rolland et al. [45] and Cartwright and Barnicoat [47] escaped metamorphic reequilibration prior to the second burial episode. Also indicated are the ages of the eclogite facies metamorphism (from Duchêne et al. [51]; Rubatto et al. [13]; Lapen et al. [52]; Rubatto and Hermann, [53]), of the first exhumation episode (from Reddy et al. [20]) and of the final exhumation to the surface (zircon fission track, Malusa' et al. [54]). The deformation and metamorphic history of the eclogite facies Piemonte units in the study area is reported in the schematic diagrams b, c and d. An early tectonic burial with HP metamorphism (b) is followed by exhumation in the footwall of an extensional shear zone (c) and by folding and reburial (d). Stars indicate the position of a marker point during the first burial episode (1), at the end of the first exhumation episode (2) and during its second burial event (3).

Exhumation after the eclogitic event culminated in metamorphism at ca. $0.20-0.35 \mathrm{GPa}$. This exhumation episode is well documented to the north of our study area, where it has been shown that the eclogitic Piemonte unit was exhumed at the footwall of an extensional shear zone located at the contact with the overlying blueschist Piemonte unit [20]. This contact can be followed also in our study area, where it is underlined by shear fabrics and slices of exotic rock units (Figs. 1b and 2a,b). ALP0481 lies in the footwall of the contact, only a few hundred meters from it (Fig. 1b). Therefore we suggest that its exhumation from ca. $1.5 \mathrm{GPa}$ to $P=0.20-0.35 \mathrm{GPa}$ was accommodated by the activity of this regional-scale extensional shear zone (Fig. 6c). The static overprint of extension-related shear fabrics by amphibole $1+$ albite symplectites at $P=0.20-0.35 \mathrm{GPa}$ also indicates that exhumation was achieved through the observed extensional shearing.

As abundant macro- (Fig. 1b), meso- (Fig. 2c) and microstructural (Fig. $3 \mathrm{f}$ and $\mathrm{g}$ ) observations reveal, the shearing episode was followed by several folding episodes, most notably the pervasive $\mathrm{F}_{3}$ upright and $\mathrm{F}_{5}$ recumbent folding. Upright folding of extensional structures indicates that a deformation mode switch from extension to shortening affected the area [8]. The crystallization of the symplectites containing amphibole 1 and plagioclase preceded $F_{3}$, as indicated by subgrain rotation recrystallization affecting both plagioclase and amphibole crystals in the hinge areas of $\mathrm{F}_{3}$ folds. On the other hand, the assemblage amphibole 2-epidote-chlorite-plagioclase, which is indicative of the second burial episode, is never observed to be affected by $\mathrm{F}_{3}$ folding and amphibole 2 is more commonly observed in the hinge zone of $\mathrm{F}_{3}$ folds. This is taken to indicate that the crystallization of amphibole 2 was syn- to post- $F_{3}$. Therefore, the increase in pressure recorded from amphibole 1 to amphibole 2 is the result of the switch from extensional to shortening deformation observed in the area. Shortening deformation indicates that renewed crustal (or lithospheric) thickening took place, culminating in reburial of the studied rocks to $P=0.65-0.80 \mathrm{GPa}$, in epidote-amphibolite conditions (Figs. 5 and $6 \mathrm{c}$ ).

The resulting $P T$ path is markedly dissimilar to those already published for the eclogitic Piemonte unit of the Western Alps, which are characterized by clockwise trajectories with a single burial-exhumation cycle (Fig. 6a; e.g. [36,45-47]).

In Fig. 6a the $P T$ path obtained in this study is compared to other estimates from an area located to the southwest of the Gran Paradiso Massif [45] and from the Zermatt-Saas zone, to the north of the Aosta-Ranzola fault [46]. Both $P T$ paths intersect or almost intersect the one obtained in our study in proximity of the conditions estimated for the crystallization of amphibole 2. However, no mineral assemblages indicative of an early exhumation phase are reported. This may indicate that the samples studied by Rolland et al. [45] and Cartwright and Barnicoat [47] 
escaped metamorphic re-equilibration prior to the second burial episode.

Therefore, this study shows that rocks that are part of orogenic belts may be able to record metamorphic histories significantly more complex than hitherto recognized. In particular, several burial-exhumation cycles can be observed in single rocks. Such behaviour had already been predicted on the basis of structural $[6,8,9]$ and geochronological [11] studies. The delay with which metamorphic evidence has been found is probably a reflection of the fact that the metamorphic record is often incomplete with respect to the real $P T$ evolution undergone by rocks in orogenic belts. In general circumstances, only a few snapshots of the $P T$ evolution of a rock find expression in the metamorphic record. This discrete distribution of points in the $P T$ space is generally converted into a continuous $P T$ "path" by linking the few data points that have been obtained. This practice may lead to incorrect inferences on the $P T$ trajectories followed by rock units between two distinct metamorphic episodes (e.g. [48]). In this respect we are aware of the fact that the $P T$ path proposed for the Piemonte units in the study area (Figs. 5 and 6a) may not represent the real $P T$ trajectory followed by the studied rock during Alpine orogenesis. Any sort of path could have been followed between the crystallization of the different omphacite and amphibole generations. However, for simplicity, we chose to link the points whose position has been determined in the $P T$ space with straight lines.

\subsection{Geothermal gradients}

First order estimates of the geothermal gradients for the two episodes of tectonic burial and exhumation can be derived from the $P T$ conditions of crystallization calculated for the different metamorphic mineral assemblages. Assuming an average density of $3 \mathrm{~g} / \mathrm{cm}^{3}$ for the overburden, a gradient of ca. $11{ }^{\circ} \mathrm{C} / \mathrm{km}$ can be estimated for the first burial episode. This value is in line with thermal gradients considered typical of subduction zone environments (e.g. [49]). In contrast, a markedly higher gradient of ca. $47^{\circ} \mathrm{C} / \mathrm{km}$ was characteristic of the final part of the first exhumation episode, assuming final conditions of $P=0.30 \mathrm{GPa}$ and $T=420{ }^{\circ} \mathrm{C}$ and again an average density of $3 \mathrm{~g} / \mathrm{cm}^{3}$. Closely spaced isotherms, which are typically found in terranes affected by lithospheric extension, are required for such steep geothermal gradients. Extensional tectonism was indeed occurring during this first exhumation event, although the scale of it is a matter of controversy (e.g. [21,50]). A decrease in thermal gradient from this first exhumation episode to the second burial episode, which was characterized by a gradient of ca. $20-28^{\circ} \mathrm{C} / \mathrm{km}$, is observed. Such decrease may indicate a change in tectonic environment. Folding of the extensional fabrics suggests a renewed episode of crustal (or lithospheric) thickening, which could account for the observed lower thermal gradient. Incomplete thermal relaxation related to slow conduction of heat may account for the still high values that have been estimated, which are higher than those normally observed in areas characterized by crustal thickening.

\subsection{Geochronological constraints}

Abundant published geochronological studies from the Piemonte units allow to constrain the timing of the tectonometamorphic evolution outlined above. Tectonic burial resulted in eclogite facies metamorphism in the Lago di Cignana and Monviso units, both belonging to the Piemonte unit, at ca. 50-44 Ma (Fig. 6a; [13,51-53]). This episode was followed by the orogen-scale exhumation of the eclogitic Piemonte units from underneath the blueschist units, which was dated at ca. $42-38 \mathrm{Ma}$ in the north-western Alps (Fig. 6a; [20]). Zircon fission track ages from the nearby Gran Paradiso massif (Fig. 1) indicate that the studied rocks cooled below $250{ }^{\circ} \mathrm{C}$ by ca. $31 \mathrm{Ma}$ (Fig. 6a; [54]).

Therefore, in only 13-19 Ma the studied rocks went from a depth of ca. $50 \mathrm{~km}$ to ca. $5-8 \mathrm{~km}$ in an extensional setting, were then reburied to ca. $15-20 \mathrm{~km}$ in a shortening setting and finally re-exhumed to shallow crustal levels (Figs. 5 and 6).

\subsection{Geodynamic setting}

This study indicates that rock units in orogenic belts may experience multiple burial-exhumation cycles and deformation mode switches from shortening to extension and vice versa. In particular, exhumation episodes are related to extensional deformation whilst shortening culminates in tectonic burial (Fig. 6).

Hints of a similarly complex tectonometamorphic history can be found in other orogens worldwide [711,55-58]. Indications of pressure cycles are present both in Cuba [57] and in the Ordfordville belt in the USA [55] and may be even inferred from published literature on the Western Alps [59], possibly indicating that pressure cycles are a common feature of the Alpine orogen.

The relevance of this study resides in the fact that the wealth of existing studies on the Western Alps allows us to join together for the first time petrological, structural and geochronological data to provide a new unified perspective on the process of orogenesis. As a consequence, 
TECTONIC MODE SWITCH MODEL
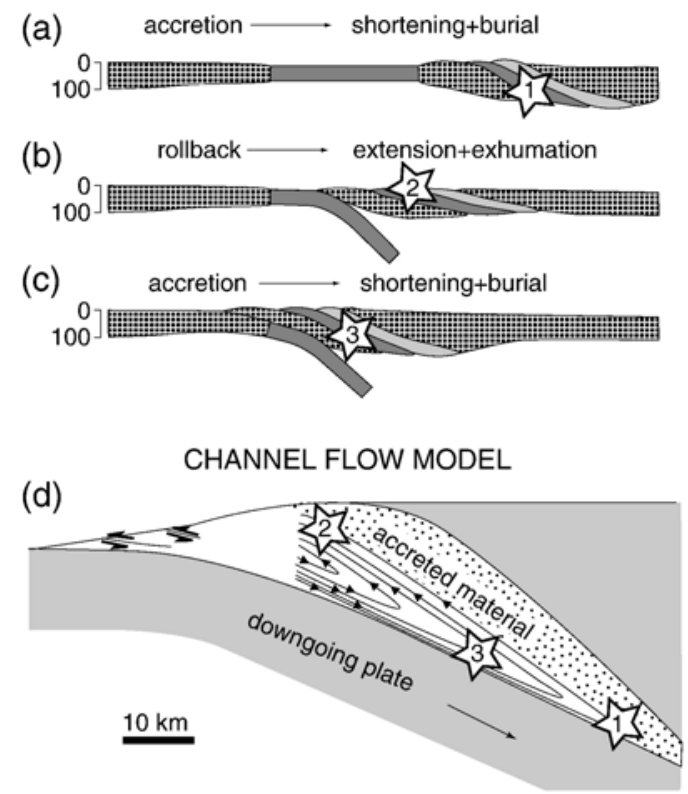

(e)

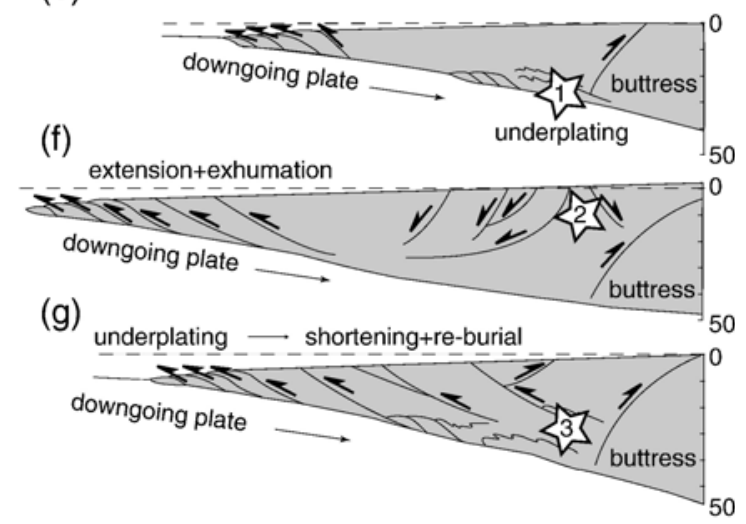

Fig. 7. Tectonic models for the evolution of orogens. The tectonometamorphic history experienced by the studied rocks may be a result of tectonic mode switches (a, b, c modified after Lister et al. [60]). In (a) a continental ribbon is accreted to the orogen, inducing shortening and burial. As plate convergence continues, a new subduction zone is created in the foreland (b). As the hinge of the subduction zone rolls back the whole orogen is thrown into extension and rock units get exhumed. The arrival of a new mass of continental material at the subduction zone (c) results in renewed shortening and reburial. An alternative tectonic model advocating corner flow with forced flow in the subduction channel is presented in (d) (modified after Cloos [62]). Black arrow indicates the paths followed by material points during their exhumation. The observed tectonometamorphic evolution is also compatible with the critical taper model of Platt [61]. As the rear of the orogenic wedge is thickened by underplating of new material (e), the longitudinal stress may become tensional, resulting in orogenic extension (f). As new material gets underplated $(\mathrm{g})$ the rear of the wedge is thickened again and rock units undergo reburial. Stars indicate the position of a marker point during the first burial episode (1), at the end of the first exhumation episode (2) and during its second burial event (3). we suggest that models of orogenesis have to take into account that: (1) rock units may experience multiple burial-exhumation cycles during an orogenic cycle; (2) these burial-exhumation cycles are coupled with shortening-extension cycles; (3) the duration of each cycle is $<10 \mathrm{Ma}$.

Such characteristics had already been predicted by the tectonic mode switch model [60] but can also be reconciled with the critical taper model [61] and the corner flow model $[62,63]$ (Fig. 7). Although discriminating between the aforementioned models is beyond the scope of this contribution, we wish to outline how and to what extent they succeed in predicting the tectonometamorphic evolution emerging from the data presented in this paper. We believe that further studies will be necessary in order to ascertain the geodynamic setting in which the above evolution took place. In the following we simply wish to state the terms of the problem.

These models present substantial differences, both in the scale of the deformation mode switches and in their geodynamic significance. In the tectonic mode switch model (Fig. 7a,b,c; [60]) the switches are orogenic in scale and involve the whole lithosphere. In the corner flow model (Fig. 7d; [62,63]) and in the critical taper model (Fig. 7e,f,g; [61]) the switches involve exclusively crustal material and are a result of the internal dynamics of an evolving orogenic wedge. In the tectonic mode switch model [60], as a continental terrane is accreted to the orogen, the entire orogenic belt may be subject to shortening deformation (Fig. 7a). Related lithospheric thickening culminates in burial of rock units and high pressure metamorphism. As subduction resumes in a more external position, rollback of the subduction zone hinge may result in trench-directed extension of the over-riding lithosphere [64], leading to exhumation of rock units (Fig. 7b). If another continental ribbon or a continental margin approaches the subduction zone and is accreted to the orogen (Fig. 7c) renewed shortening results in another burial episode. This tectonic evolution requires a complex palaeogeographic setting characterized by the alternance of continental and oceanic plates and microplates. Such complicated palaeogeography seems to have been characteristic of the west branch of the Tethys in the Early Tertiary (see Froitzheim [65] for a review).

In the corner flow model, sediments that reach eclogite-facies depths as a result of subduction (Fig. 7d) are then constrained by the over- and underlying mantle and are forced to circulate within the so-defined corner. Downward motion of the subducting slab may result in HP conditions being achieved. Once the tip of the corner is reached the rock gets exhumed. After reaching the surface, rocks may become recoupled to the descending plate and 
experience other burial-exhumation cycles. The turnaround time for each cycle has been estimated as $2 \mathrm{Myr}$ [62]. Gerya and Stökhert [63] have recently presented a more refined version of the corner flow model where once again the time scales for the burial-exhumation cycles are remarkably similar to those found in the Western Alps. Although the structural history of the rock units was not investigated by the authors, it is reasonable to postulate that, during the first exhumation episode, the exhuming rocks would be floored by a thrust and roofed by an extensional shear zone (Fig. 7d). A similar geometry has been proposed for other rock units for which corner flow has been indicated as a viable exhumation mechanism (e.g. [66]). Such shear zones may then be refolded in a later phase during the second reburial event. However, the lateral continuity of the extensional shear zone that accommodated the exhumation of part of the eclogite facies Piemonte unit (Fig. 1) seems to contradict the expected chaotic nature of the return flow. Furthermore, the corner flow model requires the existence of a long-lasting subduction zone in front of the evolving orogen. This implies a relatively simple palaeogeographic setting, in contrast to the one necessary for the tectonic switch model and commonly accepted for the Western Alps.

The critical taper model allows multiple switches from shortening to extensional deformation at the rear of the wedge [61]. Such switches are induced by the tendency to maintain a stable configuration in which the gravitational forces generated by the surface slope of the orogen are balanced by the subduction-related traction on its bottom side [61]. Sudden underplating episodes would result in an overthickened wedge and HP metamorphism (Fig. 7e). The original taper will then be restored through extensional deformation resulting in exhumation of rock units (Fig. 7f). Renewed underplating (Fig. $7 \mathrm{~g}$ ) would result in repetitions of these cycles.

Therefore, both corner flow, critical taper and tectonic mode switch models can potentially account for the tectonometamorphic evolution observed in the Piemonte units of the Western Alps and the time scales involved with its different stages. However, the three models imply radically different tectonic settings. The corner flow model implies steady-state, with thermal structure and lithospheric thickness showing little or no variations over tens of million years. Tectonic mode switches and critical taper model, instead, result in sudden collapses and surges of the orogenic belt. However, in the tectonic mode switch model the switches are lithospheric in scale, whilst in the critical taper model they involve the crust only. This difference is likely to have a fundamental impact on the thermal structure of the convergent margins and on their lithospheric thickness. Further studies will be necessary to provide better constraints on the geodynamic setting in which the observed $P T$ cycles and deformation mode switches take place.

\section{Conclusion}

This study shows that the eclogite facies Piemonte units in the Western Alps experienced two burial-exhumation cycles and deformation mode switches. Such evolution may be characteristic of other orogenic belts. Tectonic burial is a result of crustal (or lithospheric) thickening whilst exhumation occurs in response to crustal (or lithospheric) extension. Less than $10 \mathrm{Myr}$ are required for the completion of each individual burialexhumation cycle. Different existing models can account for the observed tectonometamorphic evolution. Discriminating between them will have fundamental bearings on understanding lithospheric evolution at plate margins.

\section{Acknowledgments}

A. Okamoto is thanked for providing details on amphibole geothermobarometry. G. Airoldi, G. Quaranta, A. Vitale Brovarone and E. Guasti are thanked for the help in the field. Research supported by an Australian Research Council Discovery grant. Review by N. Froitzheim helped to improve the paper.

\section{References}

[1] J.F. Dewey, Extensional collapse of orogens, Tectonics 7 (1988) 1123-1139.

[2] J.P Platt, R.L.M. Vissers, Extensional collapse of thickened continental lithosphere: a working hypothesis for the Alboran Sea and Gibraltar arc, Geology 17 (1989) 540-543.

[3] C. Beaumont, S. Ellis, J. Hamilton, P. Fullsack, Mechanical model for subduction-collision tectonics of Alpine-type compressional orogens, Geology 24 (1996) 675-678.

[4] U. Ring, M.T. Brandon, S.D. Willett, G.S. Lister, Exhumation processes, in: U. Ring, M.T. Brandon, S.D. Willett, G.S. Lister (Eds.), Exhumation processes: normal faulting, ductile flow and erosion, vol. 154, Geological Society, London, 1999, pp. $1-27$.

[5] P.C. England, A.B. Thompson, Pressure-temperature-time paths of regional metamorphism I. Heat transfer during the evolution of regions of thickened continental crust, J. Petrol. 25 (1984) 894-928.

[6] N. Froitzheim, S.M. Schmid, P. Conti, Repeated change from crustal shortening to orogen-parallel extension in the Austroalpine units of Graubunden, Eclogae Geol. Helv. 87 (1994) 559-612.

[7] J.C. Balanyà, V. Garcia-Duenas, J.M. Azañón, Alternating contractional and extensional events in the Alpujarride nappes of the Alboran Domain (Betics, Gibraltar Arc), Tectonics 16 (1997) $226-238$. 
[8] T.J. Rawling, G. Lister, Oscillating modes of orogeny in the Southwest Pacific and the tectonic evolution of New Caledonia, in: U. Ring, M.T. Brandon, S.D. Willett, G.S. Lister (Eds.), Exhumation processes: normal faulting, ductile flow and erosion, vol. 154, Geological Society, London, 1999, pp. 109-127.

[9] J.M. Azañón, A. Crespo-Blanc, Exhumation during a continental collision inferred from the tectonometamorphic evolution of the Alpujarride Complex in the central Betics (Alboran domain, SE Spain), Tectonics 19 (2000) 549-565.

[10] W.J. Collins, Hot orogens, tectonic switching, and creation of continental crust, Geology 30 (2002) 535-538.

[11] M.A. Forster, G.S. Lister, Several distinct tectonometamorphic slices in the Cycladic eclogite-blueschist belt, Greece, Contrib. Mineral. Petrol. 150 (2005) 525-545.

[12] G. Rosenbaum, G.S Lister, C. Duboz, Relative motions of Africa, Iberia and Europe during Alpine orogeny, Tectonophysics 359 (2002) 117-129.

[13] D. Rubatto, D. Gebauer, M. Fanning, Jurassic formation and Eocene subduction of the Zermatt-Saas-Fee ophiolites: implications for the geodynamic evolution of the Central and Western Alps, Contrib. Mineral. Petrol. 132 (1998) 269-287.

[14] P. Bearth, Die Ophiolite der Zone von Zermatt-Saas Fee, Beitr. Geol. Kt. Schweiz 132 (1967) 1-130.

[15] G.V. Dal Piaz, The Austroalpine-Piedmont nappe stack and the puzzle of Alpine Tethys, Mem. Sci. Geol. Padova 51 (1999) 155-176.

[16] M. Ballèvre, O. Merle, The Combin fault: compressional reactivation of a Late Cretaceous-Early Tertiary detachment fault in the Western Alps, Schweiz, Mineral. Petrogr. Mitt. 73 (1993) 205-227.

[17] S. Schwartz, J.M. Lardeaux, S. Guillot, P. Tricart, Diversité du métamorphisme éclogitique dans le massif ophiolitique du Monviso (Alpes occidentales Italie), Geodin. Acta 13 (2000) 169-188.

[18] M. Ballèvre, J.R. Kienast, J.P. Vuichard, La nappe de la DentBlanche (Alpes occidentales): Deux unités austroalpines indépendantes, Eclogae Geol. Helv. 79 (1986) 57-74.

[19] S.M. Reddy, J. Wheeler, R.A. Cliff, The geometry and timing of orogenic extension: an example from the Western Italian Alps, J. Metamorph. Geol. 17 (1999) 573-589.

[20] S.M. Reddy, J. Wheeler, R.H.W. Butler, R.A. Cliff, S. Freeman, S. Inger, C. Pickles, S.P. Kelley, Kinematic reworking and exhumation within the convergent Alpine Orogen, Tectonophysics 365 (2003) 77-102.

[21] M.A. Forster, G.S. Lister, R. Compagnoni, D. Giles, Q. Hills, P.G. Betts, M. Beltrando, E. Tamagno, Mapping of oceanic crust with HP to UHP metamorphism: the Lago di Cignana Unit (Western Alps), in: G. Pasquaré, C. Venturini (Eds.), Mapping geology in Italy, Servizio Geologico d'Italia, 2004, pp. 276-282.

[22] J. Wheeler, R.W.H. Butler, Criteria for identifying structures related to true crustal extension in orogens, J. Struct. Geol. 16 (1994) 1023-1027.

[23] R. Nervo, R. Polino, Un lembo di cristallino Dent Blanche alla Torre Ponton (Valle d'Aosta), Boll. Soc. Geol. Ital. 96 (1976) 647-657.

[24] E. Paganelli, R. Compagnoni, R. Nervo, S. Tallone, Il lembo Austroalpino di Eaux Rousses e le sue relazioni con la Zona Ofiolitica Piemontese nell alta Valle di Cogne, Valle d'Aosta meridionale, in: R. Polino, R. Sacchi (Eds.), Atti convegno AlpiAppennino, Peveragno, Acc. Naz Sci. dei XL, Scritti e Doc., vol. 14,1995 , pp. 335-348.

[25] G. Elter, Contribution à la connaissance du Briançonnais interne et de la bordure piémontaise dans les Alpes Graies nord- orientales et considérations sur le rapports entre les zones du Briançonnais et des Schistes Lustrés, Mem. Ist. Geol. Mineral. Univ. Padova 28 (1972) 1-19.

[26] C.W. Passchier, R.A.J. Trouw, Microtectonics, Springer Verlag, 1995.

[27] J.R. Vearncombe, The structure of the Gran Paradiso basement massif and its envelope, Western Alps, Eclogae Geol. Helv. 78 (1985) 49-72

[28] J. Carreras, E. Druguet, A. Griera, Shear zone-related folds, J. Struct. Geol. 27 (2005) 1229-1251.

[29] S. Bucher, C. Ulardic, R. Bousquet, S. Ceriani, B. Fugenschuh, Y. Gouffon, S.M. Schmid, Tectonic evolution of the Briançonnais units along a transect (ECORS-CROP) through the ItalianFrench Western Alps, Eclogae Geol. Helv. 97 (2004) 321-345.

[30] B.E. Leake, A.R. Woolley, C.E.S. Arps, W.D. Birch, M.C. Gilbert, J.D. Grice, F.C. Hawthorne, A. Kato, H.J. Kisch, V.G. Krivovichev, K. Linthout, J. Laird, J. Mandarino, W.V. Maresch, E.H. Nickel, N.M.S. Rock, J.C. Schumacher, D.C. Smith, N.C.N. Stephenson, L. Ungaretti, E.J.W. Whittaker, G. Youzhi, Nomenclature of amphiboles; report of the Subcommittee on Amphiboles of the International Mineralogical Association Commission on new minerals and mineral names, Mineral. Mag. 61 (1997) 295-321.

[31] O. Müntener, J. Hermann, V. Trommsdorff, Cooling history and exhumation of lower-crustal granulite and upper mantle (Malenco Eastern Central Alps), J. Petrol. 41 (2000) 175-200.

[32] B.W. Evans, Phase relations of epidote-blueschist, Lithos 25 (1990) 3-23.

[33] W.A. Deer, R.A. Howie, J. Zussman, An introduction to the rockforming minerals, second ed., Longmann, 1992.

[34] T. Holland, The experimental determination of activities in disordered and short-range ordered jadeitic pyroxenes, Contrib. Mineral. Petrol. 82 (1983) 214-220.

[35] B. Reynard, M. Ballèvre, Coexisting amphiboles in an eclogite from the Western Alps: new constraints on the miscibility gap between sodic and calcic amphiboles, J. Metamorph. Geol. 6 (1988) 333-350.

[36] M.I. Spalla, J.M. Lardeaux, G.V. Dal Piaz, G. Gosso, B. Messiga, Tectonic significance of Alpine eclogites, J. Geodyn. 21 (1996) 257-285.

[37] E.H. Brown, The crossite content of $\mathrm{Ca}$-amphibole as a guide to pressure of metamorphism, J. Petrol. 18 (1977) 53-72.

[38] J. Laird, A.L. Albee, Pressure, temperature and time indicators in mafic schist: their application to reconstructing the polymetamorphic history of Vermont, Am. J. Sci. 281 (1981) 127-175.

[39] F.S. Spear, An experimental study of hornblende stability and compositional variability in amphibolite, Am. J. Sci. 181 (1981) $697-734$.

[40] L. Ungaretti, B. Lombardo, C. Domeneghetti, G. Rossi, Crystalchemical evolution of amphiboles from eclogitised rocks of the Sesia-Lanzo Zone, Italian Western Alps, Bull. Minéral. 106 (1983) 645-672.

[41] A. Okamoto, M. Toriumi, Optimal mixing properties of calcoc and subcalcic amphiboles' application of Gibbs' method to the Sanbagawa schist, SW Japan, Contrib. Mineral. Petrol. 146 (2004) 529-545.

[42] M.J. Apted, J.G. Liou, Phase relations among greenschist, epidote-amphibolite and amphibolite in a basaltic system, Ame. J. Sci. 283 (1983) 328-354.

[43] T. Holland, J. Blundy, Non-ideal interactions in calcic amphiboles and their bearing on amphibole-plagioclase thermometry, Contrib. Mineral. Petrol. 116 (1994) 433-447. 
[44] M. Zenk, B. Schulz, Zoned Ca-amphiboles and related P-T evolution in metabasites from the classical Barrovian metamorphic zones in Scotland, Mineral. Mag. 68 (2004) 769-786.

[45] Y. Rolland, J.M. Lardeaux, S. Guillot, C. Nicollet, Extension synconvergence, poinçonnement vertical et unités métamorphiques contrastées en bordure ouest du Grand Paradis (Alpes FrancoItaliennes), Geodin. Acta 13 (2000) 133-148

[46] P. Agard, P. Monié, L. Jolivet, B. Goffé, Exhumation of the Schistes Lustrés complex: in situ laser probe Ar40/Ar39 constraints and implications for the Western Alps, J. Metamorph. Geol. 20 (2002) 599-618.

[47] I. Cartwright, A.C. Barnicoat, Petrology, geochronology, and tectonics of shear zones in the Zermatt-Saas and Combin zones of the Western Alps, J. Metamorph. Geol. 20 (2002) 263-281.

[48] P.J. O'Brien, Garnet zoning and reaction textures in overprinted eclogites, Bohemian Massif, European Variscides: a record of their thermal history during exhumation, Lithos 41 (1997) 119-133.

[49] F.S. Spear, Metamorphic phase equilibria and pressure-temperature-time paths, Mineralogical Society of America, monograph, second ed., 1995.

[50] J. Wheeler, S.M. Reddy, R.A. Cliff, Kinematic linkage between internal zone extension and shortening in more external units in the NW Alps, J. Geol. Soc. (Lond.) 158 (2001) 439-443.

[51] S. Duchêne, J. Blichert-Toft, B. Luais, P. Télouk, J.M. Lardeaux, F. Albarède, The Lu-Hf dating of garnets and the ages of the Alpine high-pressure metamorphism, Nature 387 (1997) $586-589$

[52] T.J. Lapen, C.M. Johnson, L.P. Baumgartner, N.J. Mahlen, B.L. Beard, J.M. Amato, Burial rates during prograde metamorphism of ultra-high-pressure terrane: an example from Lago di Cignana, Western Alps, Italy, Earth Planet. Sci. Lett. 215 (2003) 57-72.

[53] D. Rubatto, J. Hermann, Zircon formation during fluid circulation in eclogites (Monviso, Western Alps): implications for $\mathrm{Zr}$ and $\mathrm{Hf}$ budget in subduction zones, Geochim. Cosmochim. Acta 67 (2003) 2173-2187.

[54] M. Malusà, R. Polino, M. Zattin, G. Bigazzi, S. Martin, F. Piana, Miocene to Present differential exhumation in the Western Alps: insights from fission track geochronology, Tectonics 24 (2005) TC3004, doi:10.1029/2004TC001782.
[55] F.S. Spear, D. Rumble, Pressure, temperature and structura evolution of the Orfordville Belt, West-Central New Hampshire, J. Petrol. 27 (1986) 1071-1093.

[56] C.R.L. Friend, K.A. Jones, I.M. Burns, New high-pressure granulite event in the Moine Supergroup, northern Scotland: implications for Taconic (early Caledonian) crustal evolution, Geology 28 (2000) 543-546.

[57] A. Garcia-Casco, R.L. Torres-Roldan, G. Millan, P. Monié, J. Schneider, Oscillatory zoning in eclogitic garnet and amphibole, Northern Serpentinite Melange, Cuba: a record of tectonic instability during subduction? J. Metamorph. Geol. 20 (2002) 581-598.

[58] U. Ring, P.W. Layer, High-pressure metamorphism in the Aegean, eastern Mediterranean: underplating and exhumation from the Late Cretaceous until Miocene to Recent above the retreating Hellenic subduction zone, Tectonics 22 (2003) 1022, doi:10.1029/2001TC001350.

[59] B. Messiga, M. Scambelluri, Retrograde P-T-t path for the Voltri Massif eclogites (Ligurian Alps, Italy): some tectonic implications, J. Metamorph. Geol. 9 (1991) 93-109.

[60] G.S. Lister, M.A. Forster, T.J. Rawling, Episodicity during orogenesis, Geol. Soc. London, Spec. Publ. 184 (2001) 89-113.

[61] J.P. Platt, Dynamics of orogenic wedges and the uplift of highpressure metamorphic rocks, Geol. Soc. Amer. Bull. 97 (1986) 1037-1053.

[62] M. Cloos, Flow melanges: numerical modelling and geologic constraints on their origin in the Franciscan subduction complex, California, Geol. Soc. Amer. Bull. 93 (1982) 330-345.

[63] T. Gerya, B. Stöckhert, Two-dimensional numerical modelling of tectonic and metamorphic histories at active convergent margins, Int. J. Earth Sci. (2005), doi:10.1007/s00531-005-0035-9.

[64] Z. Garfunkel, C.A. Anderson, G. Schubert, G., Mantle circulation and the lateral migration of subducted slabs, J. Geophys. Res. 91 (1986) 7205-7223.

[65] N. Froitzheim, Origin of the Monte Rosa nappe in the Pennine Alps - a new working hypothesis, Geol. Soc. Amer. Bull. 113 (2001) 604-614.

[66] J. Hermann, O. Müntener, M. Scambelluri, The importance of serpentinite mylonites for subduction and exhumation of oceanic crust, Tectonophysics 327 (2000) 225-238. 